\title{
Finanskrisen, euroen og Danmark
}

\section{Claus Vastrup}

\section{Danske erfaringer med en selvstændig valuta under den seneste finanskrise tilsiger, at Danmark opgiver denne selvstændighed og deltager i det europæiske valutariske og monetære samarbejde}

Finanskrisen 2007-09 var den tredje globale finansielle krise inden for 10 år. Den første i 1997-98 havde sit udgangspunkt i Asien, nærmere bestemt Thailand, og var forårsaget af svage finansielle institutioner og skrøbelige valutakursregimer med faste, men selvstændige valutakurser, der blev løbet over ende af spekulative kapitalbevægelser. Den anden krise var den mindre dotcom krise i 2000-01, hvor en såkaldt prisboble i aktiekurserne bristede, og kurserne derefter på det nærmeste blev halveret, hvilket førte til en mindre recession. Den tredje finansielle krise er den meget større likviditets- og bankkrise 2007-09, der har været årsag til det største realøkonomiske tilbageslag siden den store depression i 1930 'erne. Verden har oplevet andre recessioner end de her næunte siden 1930'erne, men de har ikke som de sidste 3 haft deres udspring i finansielle forhold, men $\mathrm{fx}$ i de olieproducerende landes prisforhøjelser i 1972-73 og 1979-80. Selvom finanskriser ikke er et nyt fænomen, synes de at være på fremmarch.

Euroen kom til verden for bl.a. at sikre finansiel, herunder valutarisk stabilitet i Europa. Efter mere end 10 års eksistens og en næsten overstået finanskrise kan der være grund til se på, om et af de vigtige økonomiske formål med den fælleseuropæiske mønt er blevet opfyldt, og hvordan finanskrisen 2007-09 har udspillet sig i Europa. Formålet er til sidst at kunne sige noget om den internationale finanskrise og euroens betydning for Danmark.

Den nuværende krise har - hvis man ser bort fra problemerne i den engelske bank Nothern Rock - sit udspring i det amerikanske finansi- 
elle system, men bredte sig med lynets hast til resten af verden. Krisen kan formentlig bedst analyseres ved at betragte det internationale og især amerikanske finansielle system som et korthus, der gradvist var blevet mere skrøbeligt op til krisens udbrud i 2007.

Korthuset blev her ramt af et væsentligt, men i sig selv ikke alt ødelæggende stød i form af betalingsstandsninger på amerikanske huslån ydet mod yderliggende pant i fast ejendom. Den direkte årsag til betalingsstandsningerne var, at en boble i huspriserne bristede hovedsageligt på grund af rentestigninger. Men der var også tale om dårlig kreditvurdering bl.a. som følge af, at långiverne planlagde efterfølgende at handle med disse huslån.

Derfor skabte betalingsstandsningerne usikkerhed hos alle finansielle aktører om, hvem der sad med tabene. Usikkerheden var en følge af sammenbinding, fornyet opsplitning og især videresalg af de omtalte lån. Usikkerheden om tab og dermed solvens førte til en kraftig indskrænkning af den indbyrdes kreditgivning mellem banker i almindelighed og dermed til bortfald af likviditet i systemet. Bankerne indskrænkede herefter kreditgivningen til deres almindelige kunder også på grund af de faldende priser på fast ejendom og andre aktiver, som bankerne og deres kunder solgte netop på grund af kreditindskrænkningen og de faldende priser.
Gennem denne nedadgående spiral bredte den finansielle krise sig til alle i den finansielle sektor, og den etablerede samtidig en overgang fra finansiel til realøkonomisk krise med faldende efterspørgsel efter især varige goder. Resultatet har været faldende produktion og stigende arbejdsløshed på grund af formuetab, kreditindskrænkning mv.

\section{Skrøbeligt finansielt system}

Hvor det konkrete stød til det finansielle system kom fra, er formentlig mindre væsentlig. Andre stød ville før eller siden være fremkommet og have ført til et lignende resultat. Det interessante er årsagerne til, at det internationale og især amerikanske finansielle system var blevet så skrøbeligt. Diskussion herom foregår stadig især i USA. Nogle lægger i den forbindelse vægt på rente- og valutakurspolitik i et internationalt perspektiv (fx Obstfeld og Rogoff (2009)), mens andre tillægger ændringer i den finansielle struktur og her især de internationale finansielle relationer ansvaret for den labile struktur (fx Caballero (2010)). Hvilken forklaring der er den rigtige, og dermed hvordan ansvaret for den finansielle krise skal fordeles mellem almindelig økonomisk politik og strukturelle forhold, er væsentlig for udformningen af den fremtidige pengepolitik, indretningen af det internationale valutasystem og reguleringen af de finansielle institutioner. 
På trods af uenighed om årsagerne er der nogenlunde enighed om, at de skal søges i ændringer, som især er indtruffet siden årtusindeskiftet, og muligvis således, at prisboblen i aktiekurserne op til krisen 2000-01 var forløber for den væentlig større finansielle krise 2007-09. De, der alene lægger vægt på den amerikanske pengepolitik (som $\mathrm{fx}$ Taylor (2009)), angiver den lange periode med lav rente siden krisen $\mathrm{i}$ aktiekurserne eller i hvert fald siden 2003 som årsag til både boblen i huspriserne, den kraftige vækst i bankernes risikovillighed og udlån samt bankernes søgen efter et højere afkast end den lave rente gennem videresalg, sammenbinding og opsplitning af deres udlån i risikoklasser og dermed anvendelsen af komplekse finansielle instrumenter.

Det synspunkt har bl.a. Bernanke (2010) søgt at tilbagevise ved statistisk at påpege, at den amerikanske pengepolitiske rente ikke har været ekstraordinært lav i forhold til inflation og beskæftigelse, og at husprisernes stigning kun dårligt forklares af renteudviklingen. Men en sådan tilbagevisning forhindrer jo ikke, at en lav pengepolitisk rente kan have lavet ulykker i forhold til andre variable som fx de amerikanske bankers større udlån og villighed til at påtage sig ricisi. Imidlertid giver tilbagevisningen Bernanke mulighed for at henvise til dårlig finansiel regulering og globale ubalancer som primære årsager til finanskrisen.

\section{USA og Kina}

Andre (bl.a. Obstfeld og Rogoff (2009) ) lægger hovedvægten på et uheldigt samspil i den økonomiske politik mellem især to hovedaktører i det politiske spil om den internationale økonomiske udvikling, nemlig USA og Kina. Dette synspunkt tillægger derfor - som også Bernanke - den globale ubalance i form af store amerikanske betalingsbalanceunderskud med tilhørende overskud i Kina en væsentlig betydning. De mener, at denne ubalance er opstået især som følge af en ekspansiv amerikansk pengepolitik samt en kinesisk valutakurspolitik, der gennem intervention i valutamarkedet i perioder har fastholdt og i hvert fald styret den kinesiske valutakurs.

Det er sket og sker med henblik på at holde en lav og konkurrencefremmende værdi i forhold til USD. Kinas opkøb af USD i valutamarkedet er herefter blevet investeret i amerikanske værdipapirer, hvilket har bidraget til at holde den amerikanske rente nede og den amerikanske aktivitet oppe og har således medvirket til at øge det amerikanske betalingsbalanceunderskud. Noget tilsvarende gælder andre asiatiske landes valutakurspolitik, men disse landes betydning har været mindre.

Resultatet af den lave amerikanske rente og en undervurderet kinesisk valuta har været bl.a. en stigning i det amerikanske betalingsbalanceunderskud fra et allerede stort un- 
derskud på 2,4 pct. i 1998 (i forbindelse med den finansielle krise i Asien) over et underskud på 4,8 pct. i 2003 til et underskud på 6 pct. i 2006 lige inden den nuværende finansielle krise - alt målt i forhold til det amerikanske BNP. Især den seneste udvikling har nogle anset for uholdbar selv på mellemlangt sigt, idet også Kinas betalingsbalanceoverskud steg meget kraftigt i perioden 2005-07. I 2007 udgjorde det kinesiske overskud 13 pct. af Kinas BNP.

De, der anser den globale ubalance for uholdbar og som væsentlig årsag til finanskrisen, havde frygtet et pludseligt stop i omverdenens finansiering af det amerikanske betalingsbalanceunderskud og derfor et pludseligt kraftigt fald i USD's internationale værdi med tilhørende negative konsekvenser for aktivitet og beskæftigelse først i omverdenen og siden i USA. Den umiddelbare svaghed ved en henvisning til den globale ubalance som forklaring på den internationale finanskrise er, at denne ikke var en krise som følge af et pludseligt og kraftigt fald i kursen på USD. Tværtimod strømmede der betydelige kapitalmængder til USA, mens krisen var på sit højeste, således at den amerikanske rente på sikre placeringer faldt, den amerikanske dollar blev apprecieret, og den amerikanske centralbank var nødt til at udlåne USD til andre landes centralbanker. På den anden side har den globale ubalance givetvis bi- draget til det lave amerikanske renteniveau.

Det tredje sæt af argumenter til forklaring af det skrøbelige finansielle system i USA lægger vægt på ændringer i strukturelle vilkår, som har forøget og især ændret den internationale fordeling af de finansielle risici. Denne forklaring inddrager godt nok de globale ubalancer, men lægger vægt på, at de er kommet i stand som følge af på den ene side veludviklede finansielle markeder og institutioner i USA, der har udbudt forholdsvis risikofrie produkter, og på den anden side en efterspørgsel efter sikre fordringer, som er kommet fra de store og voksende valutabeholdninger i Kina, andre asiatiske lande og på det senere også OPEC-landene.

Ifølge denne synsvinkel har den finansielle sektor i USA reageret på en efterspørgsel, og denne efterspørgsel har især været fra centralbanker og derfor efter forholdsvis sikre amerikanske fordringer, som er fremkommet bl.a. gennem den tidligere omtalte sammenbinding og opdeling af fordringer. Denne opdeling og salg af de sikre trancher til Kina m.fl. har efterladt de mest usikre finansielle fordringer hjemme i amerikanske banker, investeringsbanker, pensionskasser mv. Nogle af de usikre fordringer er efterfølgende blevet købt af europæiske banker, som på den måde er blevet inddraget i finanskrisen.

Opdelingen og sammenbindin- 
gen af fordringer er blevet kreditvurderet, og hele processen er i mange tilfælde blevet gennemført på en sådan måde, at fordringernes individuelle risiko nok er blevet spredt, men at den systematiske risiko samtidig er blevet forøget. De nyskabte fordringer er således blevet mere og ikke mindre afhængige af den generelle konjunkturudvikling (Coval m.fl. (2009)).

Vægten er med denne synsvinkel lagt på en uhensigtsmæssig international fordeling af risiko, hvorfor dens fortalere tillægger strukturelle ændringer i den internationale finansielle sektor og dens markeder stor betydning. Fortalerne underspiller, at den internationale risikofordeling er relateret til og forøget som følge af den globale ubalance, der igen kan være en følge af en ekspansiv amerikansk pengepolitik samt Kinas store opsparingsoverskud og en politik med styret og som regel fastlåst valutakurs over for USD. Det er ikke tilstrækkeligt at henvise til, at den finansielle krise principielt kunne være opstået alene som følge af forskelle i de finansielle strukturer mellem USA og Kina.

\section{Global uligevægt}

Ingen af forklaringsbidragene synes således hverken at kunne stå alene eller udelukkes. Den internationale finanskrise er formentlig resultatet af et samspil mellem uheldige penge- og valutakurspolitikker og tilsva- rende uheldige strukturelle forhold i den finansielle sektor. Selvom krisen ikke var en dollarkrise, har den globale uligevægt formentlig været en medvirkende årsag til både den lave amerikanske rente og boblen i huspriserne. Derfor skal det amerikanske underskud og kinesiske overskud nedbringes gennem ændringer især i den økonomiske politik, hvilket involverer en depreciering af USD, en opskrivning af den kinesiske valuta og endvidere en ændret fordeling af den samlede efterspørgsel gennem en stramning af den amerikanske finans- og pengepolitik og udgiftsforøgende kinesisk politik gennem $\mathrm{fx}$ forbedringer af de sociale sikringsordninger. Disse behov er til stede, selv om den finansielle og efterfølgende realøkonomiske krise midlertidigt har reduceret det amerikanske betalingsbalanceunderskud og det kinesiske -overskud.

Da en skæv fordeling og koncentration af en betydelig finansiel risiko også har sin andel i krisen, er der tillige behov for ændringer i den internationale og måske især den amerikanske finansielle infrastruktur. Det kan ske ved at udlicitere en del af risikoen til andre end de internationale banker og ved på banksiden at forøge modstandsdygtigheden og reducere incitamenterne til at påtage sig risiko gennem skærpede krav til bankernes egenkapital.

Der er også behov for overvågning af, om bankernes individuelt fornuftige handlinger i deres sam- 
spil og dermed systemmæssigt reducerer den finansielle stabilitet.

Den internationale finanskrise 2007-09 har som nævnt ikke været den dollarkrise mange havde ventet, og de globale ubalancer udgør kun en delmængde af årsagerne til krisen. Der har således ikke været tale om en international valutakrise, men en krise på især andre markeder i det finansielle system. Dollarens position i det internationale valutasystem og den internationale finanskrise er to næsten adskilte problemer.

\section{Også krise i Europa}

Det gælder også, at den finansielle krise er opstået i USA af årsager, der ikke har at gøre med det valutariske og monetære samarbejde i Europa. Men i en verden med globale finansog varemarkeder kan virkningerne af krisen selvfølgelig ramme både Europa og euro-zonen. Det har også været tilfældet. Den finansielle nedsmeltning ramte Europa gennem flere kanaler. Europæiske banker har som nævnt købt en del af de sammenbundne og opdelte amerikanske produkter, ligesom de europæiske banker i almindelighed også var højt gearede. Stødet fra tabene på de amerikanske huslån fik derfor også den indbyrdes tillid til og mellem europæiske banker og dermed deres likviditet til at tørre ud. Samtidig må man antage, at det udsalg af fordringer og andre aktiver, som den finansielle sektor i USA foretog i kølvandet på krisen, også omfattede europæiske aktiver, hvis priser derfor også blev presset ned.

Det dobbelte finansielle sammenbrud fik tillige med et sammenbrud i huspriserne i bl.a. Irland, Spanien (og Danmark) den europæiske og amerikanske konjunktur til at bryde sammen på nogenlunde samme tidspunkt. Faldet i Europa begyndte i 2. kvartal 2008. Lidt forsinket nedsatte ECB renten og stillede stærkt forøgede mængder af likviditet til rådighed for bankerne i euro-zonen. Den stillede tillige euro til rådighed for europæiske centralbanker uden for euro-zonen, herunder den danske. Samtidig, og det var i efteråret 2008, garanterede de europæiske regeringer for deres bankers indlån og gæld for at få bl.a. markedet for likviditet mellem bankerne til igen at fungere. I de fleste lande indskød regeringerne også forskellige former for egenkapital i bankerne.

På trods af de meget store finansielle spændinger opstod der ikke uro om de indbyrdes valutakurser i euro-zonen. Nogle vil måske sige, at der ikke findes sådanne valutakurser, mens andre vil sige, at de er fuldstændig fastlåste som følge af anvendelse af fælles møntfod. Uanset betragtningsmåde er resultatet det samme, valutarisk stabilitet. Inden euroen kom på banen, har der i situationer med finansielle kriser, mindre end den nuværende, været store udsving i de europæiske valu- 
takurser, især i forhold til kursen på DM, som dengang var det stabile anker i Europa. Det var mest udtalt under valutakrisen i EMS'en 1992-93, som fik regeringer i nogle af medlemslandene til at forlade fastkurssamarbejdet, mens centralbankerne $\mathrm{i}$ andre medlemslande var nødt til at hæve rentesatserne. Det skete i en situation, hvor hensynet til beskæftigelsen tilsagde det modsatte.

Den fælles mønt har derfor under finanskrisen 2007-09 sikret landene i euro-zonen mod valutarisk og pengepolitisk uro, herunder konkurrerende devalueringer som i 1930'erne. Samtidig har euroen gjort det muligt for ECB at føre den meget ekspansive rente- og likviditetspolitik, som er ønskelig i en situation med store kreditbegrænsninger, formuetab mv. Noget tilsvarende gælder for euro-landenes regeringer og deres finanspolitik, hvor en ekspansiv politik er nødvendig, når kreditkanalerne er tilstoppet, og rentepolitikken derfor ikke fungerer. En så ekspansiv penge- og finanspolitik havde ikke været mulig med selvstændige europæiske valutaer og mange lande med begrænsede valutabeholdninger og negative betalingsbalancer - $\mathrm{i}$ hvert fald havde det ikke været muligt $i$ alle lande, $i$ samme udstrækning og så hurtigt, som tilfældet var.

\section{Hårdt ramte euro-lande}

Alligevel har produktion og beskæf- tigelse også i euro-zonen været så hårdt ramt, at tilbageslaget i omfang kan sammenlignes med tilbageslaget i forbindelse med OPEC-landenes forhøjelse af oliepriserne i begyndelsen af 1970'ernes og selv med den verdensomspændende depression $\mathrm{i}$ 1930'erne. Nogle medlemslande har været særlig hårdt ramt. Det gælder Irland, Spanien, Portugal og Grækenland. I de to første tilfælde har det især været på grund af byggeboom og derfor en stor byggesektor, som på det nærmeste er faldet sammen under finanskrisen. I de to sidste tilfælde på grund af langvarig statsfinansielle og andre problemer. Alle fire lande kunne have undgået nogle af deres særlige problemer ved på et tidligt tidspunkt at have udvist rettidig omhu i den økonomiske politik. Det gælder især for de offentlige finanser, byggesektorernes størrelse og de store underskud på landenes betalingsbalancer, der i øvrigt er påvist i et vist omfang at hænge sammen med huspriser og byggeboom (bl.a. Eichengreen (2009), Bernanke (2010)).

I de nævnte lande og især Grækenland har de statsfinansielle problemer forøget rentespændene i forhold til resten af euro-zonen. Nogle bruger de forøgede rentespænd til at spekulere over og måske også i et delvist sammenbrud af euro-samarbejdet. Her glemmer man, at i forbindelse med Maastricht-traktaten blev sådanne rentespænd diskuteret som middel til at disciplinere med- 
lemslandene med underskud på de offentlige finanser. Traktatens fædre anså dog ikke spændene for tilstrækkelig virksomme i den henseende og valgte derfor at introducere Stabilitets- og Vækstpagtens (SVP) bestemmelser suppleret med forbud mod offentlig gældsætning, gældseftergivelse mv. Man har altså forudset, at rentespænd kunne opstå, men mente ikke, at de kunne disciplinere politikernes adfærd i forhold til den økonomisk politik, og derfor fik man SVP.

Godt 20 år efter ender man formentlig med det modsatte resultat, nemlig at rentespænd for offentlige fordringer kan blive store og være virksomme som middel til at disciplinere medlemslandene, samtidig med at SVP reelt er suspenderet. På grund af sit begrænsede omfang gælder dette også efter euro-landenes hjælpepakke til Grækenland i april 2010, også selv om denne i et vist omfang måtte danne skole. I en diskussion af den samlede stabilitet $\mathrm{i}$ euro-zonen skal man i øvrigt ikke overse, at der som følge af krisen omkring de sydeuropæiske medlemslande ikke er opstået forøget rentespænd andre steder i eurozonen og heller ikke i forhold til fx Danmark. Også af den grund er det vanskeligt at forestille sig et større sammenbrud eller opløsning af euro-samarbejdet som følge af den nuværende krise.

Hvis man hæver blikket ud over finanskrisen og ser på euro-zonen si- den oprettelsen i 1999, er det foruden stabiliteten i de interne valutakurser lykkedes at fastholde både den faktiske og forventede årlige og samlede inflation på tæt ved 2 pct., at indsnævre forskellene i medlemslandenes inflationsrater, at etablere og fastholde lave nominelle rentesatser (uden præmier for valutarisici) og at begrænse variabilitet i de makroøkonomiske variable - indtil recessionen 2008-09. Disse resultater er opnået ved hjælp af - nogle vil måske sige på trods af - medlemslandenes udstrakte grad af uafhængighed i deres finanspolitik og uafhængige regulering af og vilkår på deres arbejdsmarkeder.

USA, UK og andre især vesteuropæiske lande har i den samme periode opnået nogenlunde tilsvarende resultater. Umiddelbart er det derfor muligt, at den stabilitet i inflation, produktion og makroøkonomiske forhold, der herskede i euro-zonen fra begyndelsen af 1990'erne frem til finanskrisen 2007-09, ikke skyldes euroen som sådan, men et generelt fravær af store stød til økonomierne og/eller en generelt succesrig stabiliseringspolitik. Flere studier af, hvad der ofte kaldes 'den store moderation', tyder på, at god stabiliseringspolitik generelt har været medvirkende til de gode resultater, og spørgsmålet er herefter, om det havde været muligt uden euroen og derfor med selvstændige valutaer med tilhørende politik at opnå lige så gode resultater. 


\section{Euroen bestod prøven}

Den tvivl, som tidligere måtte have hersket om euroens bidrag til den opnåede stabilitet, blev udsat for en voldsom prøve med finanskrisen og den efterfølgende recession 200709. Som nævnt sikrede euroen i den situation valutarisk stabilitet og gjorde det muligt for landene i euro-zonen hurtigt og omfattende at lempe penge- og finanspolitikken, hvilket bidrog væsentligt til den økonomiske stabilisering. Euroen har således bestået prøven både før, under og efter det største finansielle stød i nyere tid. For så vidt angår SVP er det i højere grad et politisk end økonomisk problem, når bestemmelserne bliver suspenderet i perioder, hvor der som under finanskrisen har været et reelt behov for ekspansiv finanspolitik. De store offentlige budgetunderskud har i situationen ikke skadet det almindelige renteniveau. Det politiske problem er, at underskuddene efterfølgende kræver en betydelig opstramning af de offentlige finanser, og at der er behov for at genskabe troværdighed om den finanspolitiske holdbarhed i medlemslandene.

Finanskrisen har i almindelighed ramt europæiske lande uden for euro-zonen hårdere end lande inden for. Virkningerne af finanskrisen har været meget betydelige for fritstående lande med fleksible valutakurser som fx UK og Ungarn (for ikke at nævne Island). Faldet i vær- dien af disse landes valutaer har været større, end hensynet til en stabil hjemlig udvikling tilsiger. Samtidig har disse valutakursændringer gennem forringet konkurrenceevne også ramt $\mathrm{fx}$ fastkurslande, som handler med de fritstående lande med fleksibel valutakurs. På den måde har andre lande fået videresendt nogle af de omkostninger ved finanskrisen og recessionen, som stammer fra lande med fleksible valutakurser. Det gælder fx Danmark i forhold til UK og Sverige.

I forhold til udenforstående lande med fast valutakurs i forhold til euroen har ECB på den ene side været hjælpsom og afbødet nogle af virkningerne af finanskrisen ved at stille euro-kreditter til rådighed for bl.a. Danmark. På den anden side har ECB tilkendegivet, at lande, som ensidigt måtte indføre euroen som national valuta, ikke vil modtage likviditetsstøtte i krisesituationer (Eichengreen (2009)). Bliver denne tilkendegivelse efterlevet i en udvidet fortolkning, vil udenforstående lande med fast, selvstændig valutakurs i forhold til euroen få sværere ved at få likviditetsstøtte fra ECB i fremtidige krisesituationer. Denne mulighed er ikke blevet mindre sandsynlig, efter at den tyske regering i forbindelse med den græske krise i foråret 2010 har antydet, at medlemslande skal kunne sendes ud af euro-zonen i tilfælde af vedvarende brud på SVP's bestemmelser. Den tyske interesse synes således at være at be- 
grænse euro-samarbejdets forpligtelser og valutariske bånd til omverdenen. Derfor undervurderer de aktuelle omkostninger ved at stå uden for euro-samarbejdet i en finansiel krise formentlig omkostningerne ved at stå udenfor i fremtidige kriser.

\section{Danmark og euroen}

For Danmarks vedkommende blev spændet mellem både Nationalbankens rentesatser og markedsrenterne i forhold til de tilsvarende rentesatser i euro-zonen forøget flere gange under krisen. På samme måde blev danske pengeinstitutters likviditet sat under voldsomt pres af finanskrisen. Det var begge ændringer i den forkerte retning i en situation med udsigt til faldende produktion og beskæftigelse. Ved finansielle og valutariske st $\varnothing \mathrm{d}$ er det bedst for den samlede stabilitet at have en helt troværdig fastkurspolitik i forhold til et monetært stabilt område som euro-zonen. Hvis man skal dømme efter markedsreaktionerne, var den fulde troværdighed ikke til stede. Når de direkte rente- og likviditetsvirkninger alligevel blev begrænsede, skyldes det foruden den nævnte likviditetsstøtte fra ECB en tilsvarende støtte fra US Federal Reserve og det forhold, at Danmark med en lang og stabil historik har kunnet læne sig op ad et veletableret og stabilt euro-samarbejde.

Men det er også væsentligt under og efter en finanskrise at have råde- rum til med ekspansiv finanspolitik at støtte produktion og beskæftigelse. Det kræver selvfølgelig en rimelig situation for så vidt angår de statslige og offentlige finanser. Men en ekspansiv finanspolitik kræver også, at den valutariske stabilitet ikke herved bringes i fare. Hvis et land ikke er medlem af en monetær union, men som Danmark selvstændigt har ansvaret for sin valutakurs, er det ensbetydende med, at hensynet til den nødvendige stabilitet $\mathrm{i}$ betalingsbalance og valutastilling kan lægge begrænsninger på den finanspolitiske handlefrihed.

\section{Valutastillingen}

Noget tilsvarende gælder for Nationalbankens penge- og likviditetspolitiske råderum. Som følge af de frie kapitalbevægelser mellem Danmark og udlandet er det her især valutastillingen, som er den afgørende begrænsning. Valutastillingen kan i tilfælde af velvilje suppleres med støtte fra andre centralbanker, men i en finansiel krise næppe ved låntagning $\mathrm{i}$ markedet. Velviljen har i den aktuelle situation været til stede hos ECB og US Federal Reserve formentlig som følge Danmarks gode økonomiske situation samt krisens baggrund og omfang. Samtidig har deres likviditetsstøtte givetvis været afgørende, for at Nationalbanken kunne yde en omfattende genbelåningsadgang og likviditetsstøtte til den finansielle sektor i Danmark. 
Med begrænset valutastilling kan forventninger i markedet skabt af officielle udtalelser være afgørende for, hvordan kapitalen bevæger sig. Det er formentlig grunden til, at den danske regering og Nationalbanken under krisen ikke havde mange kommentarer om de begrænsninger, som hensynet til den valutariske stabilitet må have haft for deres beslutninger, om hvor ekspansiv finanspolitikken og hvor omfattende likviditetsstøtten til de danske pengeinstitutter kunne gøres. Da Danmark aktuelt har et betydeligt og oven i købet voksende overskud på betalingsbalancen, har det væsentligste hensyn i den aktuelle situation formentlig været valutastillingen.

Efterfølgende har Nationalbanken (Bernstein (2010)) redegjort for hvorledes udenlandske spekulanter under krisen i efteråret 2008 testede Nationalbankens mulighed for at finansiere en meget betydelig valutaudstrømning til sikring af en fast, men selvstændig dansk valutakurs. Som følge af finanskrisen var det på det værste tidspunkt i oktober 2008 ikke muligt for Nationalbanken på den danske stats vegne at låne på de internationale kapitalmarkeder til supplering af den kritisk lave valutabeholdning. Den danske statsgaranti fra samme måned for alle bankernes indskud og lån inkl. de udenlandske (bankpakke 1) var derfor vigtig til sikring også af valutakursen.
Lande og især mindre lande, som er medlem af euro-zonen, har ikke et selvstændigt ansvar for deres valutakurs. I forhold til de øvrige medlemslande er den indbyrdes valutakurs sikret af den fælles mønt, og i forhold til tredjelande er valutakursen et fælles anliggende. Som euromedlem ville Danmark derfor have et større finanspolitisk råderum, og likviditetsstøtten til pengeinstitutterne ville være ECB's støtte, som har været mere omfattende end den danske. Danmark ville i så fald heller ikke have et rentespænd betinget af valutakursrisiko og ville derfor aldrig have en højere rente end eurozonens.

Både som euro-medlem og med en selvstændig, fast valutakurs i forhold til euroen opgiver Danmark at bruge valutakursen som instrument i den økonomiske politik. På den baggrund har enkelte økonomer argumenteret for, at Danmark skal overgå til en fleksibel valuta, mens andre $\mathrm{fx}$ vismændene (DØR, Forår 2009) har argumenteret for, at Danmark ikke skal overgå til den fælles mønt, men bibeholde en selvstændig valuta med fast valutakurs i forhold til euroen. Vismændenes synspunkt er, at Danmark i så fald stadig vil have mulighed for i en presset situation at overgå til en fleksibel valutakurs. Andre ville måske nøjes med at overgå til en anden værdi af den faste valutakurs. Foruden overvejelser om, hvor sandsynligt det er, at en sådan presset situation vil op- 
stå, hvilket afhænger både af eksogene stød og den økonomiske politik og dermed den politiske stabilitet, er det helt afgørende for sådanne overvejelser, at de foreslåede ændringer af valutakursregimet får den ønskede virkning.

For det første har en variabel valutakurs på grund af spekulative kapitalbevægelser vist sig at give uønsket stor variabilitet i valutakursen og især for mindre lande muligvis heller ikke en væsentlig større uafhængighed i bestemmelsen af især den lange rente. Det ville formentlig også vise sig, at man i finanspolitikken ville være nødt til at tage hensyn til eksterne forhold, herunder betalingsbalancen. En variabel valutakurs ville formentlig samtidig betyde mindre samhandel med omverdenen.

Om en fleksibel eller på anden måde ændret valutakurs i forhold til euro-zonen vil have virkninger for eksport, import, betalingsbalance, produktion og beskæftigelse er et spørgsmål om, hvilken form for prisfastsættelse henholdsvis danske eksportører anvender på deres eksportmarkeder i euro-zonen, og euro-zonens eksportører anvender for deres eksport til Danmark dvs. i den danske import. Nyere økonomisk teori og empiri skelner her mellem en situation, hvor eksportør-producenten fastsætter sin pris på eksportmarkedet i sin egen valuta, og en situation, hvor eksportør-producenten fastsætter sin pris på eksport- markedet i importlandets valuta (se fx Corsetti og Pesenti (2008)).

Kun i det førstnævnte tilfælde vil en højere valutakurs dvs. en devaluering af eksportlandets valuta give lavere priser i importlandet og forøget efterspørgsel og dermed forøget eksport, produktion og beskæftigelse i eksportlandet. I den anden situation vil efter en devaluering importpriserne i importlandet være uændrede, efterspørgselen uændret og virkninger på det devaluerende eksportlands produktion og beskæftigelse vil derfor udeblive.

Til trods for at vismændene tillægger det betydning, at Danmark uden for euro-zonen vil kunne ændre valutakursen - denne option er det eneste af deres argumenter, der taler for at opretholde den nuværende situation med en selvstændig valuta og indtil videre fast valutakurs og ikke overgå til euroen - omtaler de ikke muligheden af sådanne forskelle i prisfastsættelsen på eksportmarkeder, men forudsætter uden videre, at alle producenter anvender prisfastsættelse i egen valuta. Vismændene forudsættes således, at valutakursen i alle situationer hurtigt og præcist påvirker betalingsbalance, produktion og beskæftigelse.

Om den ene eller den anden form for prisfastsættelse anvendes i praksis er selvfølgelig et empirisk spørgsmål. Det er imidlertid den generelle opfattelse, at ændringer i valutakurser er langt fra at slå hurtigt og fuldstændigt igennem på eks- 
port- og importpriser. Undersøgelser i forhold til det store amerikanske valutaområde tyder tillige på, at i forholdet mellem små eksportlande som Danmark og store importmarkeder som euro-zonen vil en asymmetrisk prisfastsættelse i det store lands valuta være fremherskende (Atkeson og Burstein (2008)).

Derfor vil en ændring af valutakursen for den formelt selvstændige danske krone sandsynligvis ikke være en hurtig og sikker mulighed for at påvirke den danske betalingsbalance, produktion og beskæftigelse. Vismændenes seneste diskussion af, om Danmarks med fordel kan bruge valutakursen eller euroen, udelader således væsentlige analytiske og empiriske resultater fra nyere litteratur om valutakurser.

\section{Konklusion}

Den fælles mønt har før, under og efter finanskrisen 2007-09 sikret valutarisk stabilitet og bedre økonomiske rammebetingelser i euro-zonen. Det gælder på trods af den efterfølgende krise i Grækenland. Finanskrisen har også testet Danmarks muligheder for at forsvare sin faste, men selvstændige valutakurs. På trods af valutaudstrømning og vanskeligheder med finansieringen lykkedes operationen med støtte først fra US Fed og siden fra ECB. Denne støtte og andre kriseforanstaltninger var nødvendige, selvom Danmark med sin fastkurspolitik i mange år har lænet sig op ad den valutariske stabilitet i euro-zonen. Men problemer og usikkerhed om resultatet var til stede, og da omkostningerne ved at stå uden for euro-samarbejdet formentlig vil stige som følge af eurolandenes erfaringer under og efter krisen, tilsiger de danske erfaringer med en selvstændig valuta under en finanskrise, at Danmark opgiver denne selvstændighed og deltager i det europæiske valutariske og monetære samarbejde. Både økonomisk strukturelle fordele, så som øget samhandel og arbejdsdeling, og de stabiliseringspolitiske resultater taler således for dansk euro-medlemskab.

Claus Vastrup er professor i $\not$ konomi ved Århus Universitet. Artiklen er ferdiggjort ultimo april.

Litteraturlisten fås ved at sende en mail til brita@udenrigs.dk 